\title{
VERMOGENSRECHTELIJKE STAATSBOEKHOUDING VERSUS KAMERAALSTIJL (I)
}

\author{
door Prof. Dr A. Mey
}

\section{Analyse van het probleem, dat overheidsadministratie en onderneming hebben op te lossen.}

\section{a. de kameralistiek een verouderde stijl.}

Verschillende auteurs hebben er reeds op gewezen, dat de traditionele boekhouding der Overheidsorganen - de kameraalstijl — niet voldoet aan de eisen, welke de moderne tijd aan de publieke administratie stelt, en reeds lang in gebreke bleef om aan de eisen des tijds te voldoen. Ik herinner hier aan van Gijn's critiek op de Nederlandse staatsboekhouding in "De Economist" van 1912, aan uitingen in verschillende geschriften over de wenselijkheid van een staatsbalans of gemeentebalans, aan verschillende uitingen in de kringen van de Vereniging van Nederlandse Gemeenten en het Instituut van Bestuurswetenschappen. De bekende Engelse schrijfster over staatsfinanciën Mrs Ursula Hicks merkt op, dat niet alleen ,the method of presentation of the public accounts" een overblijfsel is van conditions which have passed away", maar dat de gehele ,actual method of accounting" van de Staat ,reflects a stage of economic and political development, when accounting technique was dominated by practices appropriate to personal or family expenditure".

Hier wordt naar mijn oordeel de spijker op de kop geslagen. De administratie volgens de kameraalstijl moge gepast hebben in het kader der gezagsopvatting van de Borgia's, Machiavelli, Philippe le Bel, le Roi Soleil en van de Duitse vorsten, voor wie von Seckendorff zijn verhandeling over kameraalstijl schreef, zij past niet in de opvattingen van een democratisch bestuur. Evenmin echter schept het traditionele "koopmansboekhouden" de vorm voor de administratie van het moderne grote industriebedrijf. De modernisering van de productie-techniek, de veranderingen in de economische verhoudingen en de omvangvergroting der te besturen eenheden - sedert het midden der vorige eeuw - doen op beiden hun invloed gelden.

Beide - de overheidsadministratie en de administratie van het particuliere bedrijf - vragen op vele punten om verbetering; niette$\min$ is die verbetering verder voortgeschreden in het tweede dan wel in het eerste geval. De ,accounting-technique" wordt daar niet meer beheerst door ",practices appropriate to personal or family expenditure", hoewel in het kardinale vraagstuk van de waarden, welke te administreren $z$ ijn, de traditionale methoden nog domineren.

De verwarring tussen ,uitgaven" en ,,kosten" — waarover ik enige 
maanden geleden schreef - beheerst nog beide administraties, maar die verwarring ligt dieper verankerd in de kameralistiek dan in de moderne bedrijfsboekhouding. Dit is echter geen principieel onderscheid, maar alleen een phasenverschil in de ontwikkeling. Door de activiteit van accountants in de particuliere ondernemingen ligt de ontwikkeling der administratie daar enige paardlengten vóór. Dit verschil in stadium wordt veelal door administratie-deskundigen versleten voor een principieel verschil in het karakter der huishouding (b.v. consumptie- of productie-huishouding). Analyse der verschillen in karakter leert echter, dat hetgeen de traditie als zodanig noemt (boven aangegeven) slechts op oppervlakkige waarneming berust. Constatering van andere verschillen dan die, welke de kameraalstijl van de „dubbele boekhouding" onderscheidt, wordt daardoor verkregen.

De kardinale factor in beide administraties is, dat de boekhouding moet worden het werktuig ter besturing van de organisatie, ter beheersing van de doelmatigheid van de bedrijfsvoering, ,the tool of management".

De strijd, die t.a.v. dat bedrijfsleven gevoerd wordt om het bestuursapparaat te rationaliseren, de interne en externe verslaglegging te verbeteren, de mogelijkheid te scheppen functionele decentralisatie te combineren met ongebroken centrale leiding, moet evenzeer in het openbaar bestuursapparaat gestreden worden. Het kardinale in de problematiek van de organisatie van het bestuursapparaat is in beide gevallen gelijk, de verschillen in juridische structuur zijn in het vraagstuk van die organisatie van secundair belang. Het probleem van de verantwoordelijkheid van de leiding aan een hoger belang, vertoont in beide gevallen op vele punten typische overeenkomsten. Ik ben geneigd te stellen, dat hetgeen de - nog geldende - traditionele beschouwing der administratieve organisatie als karakteristiek naar voren brengt, niet meer is dan een uitvloeisel uit verouderde opvattingen van standsverschillen tussen hogere ambtenaren (la noblesse de robe du Roi Soleil!) en de „nijveren" (le tiers état!). Mrs Hicks schijnt dezelfde achtergedachte te hebben.

$\mathrm{Bij}$ het bestuur der gemeenschapshuishouding en hare veel vertakte organen - en bij dat van het ondernemende concern - dringt de noodzaak naar voren om de verschillende functies en organen van het bestuursapparaat in eigen betekenis en werking naar voren te laten treden. Dit geldt ten aanzien van de projectie van nieuwe organen en van hun uitbreiding. Het geldt terzake van het ontwerpen van bestuursplannen, terzake van de vastlegging van de uitvoering en van de contrôle op het gevoerde beleid. Derhalve dienen ook financiering en exploitatie in hun onderscheid naar voren te treden. Het uit het financieren volgend uitgeven voor het verwerven van waarden, dient dus gescheiden te worden van het - uit de exploitatie volgend - verbruik van waarden, welke op vroeger tijdstippen (onder andere gelding van waarden van tijd, stof of kracht) verworven werden. Dit geldt voor alle huishoudingen en voor alle producties; zowel van die van goederen, die ter markt worden aangeboden als voor de voortbrenging van beschikbaarheidsnuttigheden (zoals de openbare orde, de nationale integriteit en dergelijke).

\section{b. het waardemoment en de moderne techniek.}

Het waardeprobleem komt in alle huishoudingen voor. Het probleem treedt in het bijzonder daar op, waar een verwerven van waardevolle zaken voor later verbruik noodzakelijk is, m.a.w. waar het z.g. ,repro-

m a b blz. 319 
ductief verbruik" optreedt en dus de activiteiten van "verwerven" en produceren of exploiteren als ,verbruiken van verworven waarden" in hun functioneel onderscheid naar voren treden. De welvaartstoestand wordt wel in geld - als algemene waardemeter - uitgedrukt, maar wordt alleen door concrete goederen bepaald. De verduistering van het inzicht door de z.g. ".geldsluier" speelt ook hier een rol naast andere oorzaken, welke ten deze het inzicht vertroebelen.

$\mathrm{B}_{\mathrm{ij}}$ de voortbrenging van beschikbaarheidsnuttigheden door de gemeenschapshuishouding, zowel als bij de voortbrenging van per eenheid verkoopbare goederen of diensten door gemeenschapshuishouding of onderneming spreekt - in het merendeel der gevallen - dat functionele onderscheid tussen verwerven en verbruiken. Het komt mij voor, dat de consequentie van de verandering der productie door de z.g. ,industriële revolutie" noch in de administratie van het bedrijfsleven, noch in die van de gemeenschapsorganen voldoende is uitgewerkt. Die verandering kan - zeer algemeen - getypeerd worden door produceren in anticipatie op de toekomstige behoeften, waarin de productie wenst te voorzien. Daartoe is nodig vooraf te verwerven: voorraden werkeenheden opgesloten in duurzame productiemiddelen, voorraden grondstoffen, voorraden werkeenheden van menselijke arbeid, welke voor de productie specifieke betekenis hebben en niet gemakkelijk vervangbaar $z$ ijn. Volledige uitwerking van die verandering in de administratie kan pas verkregen worden door toepassing van de bedrijfseconomische theorie, zoals die door Limperg werd geconcipieerd. In die theorie toch wordt de waarde van het tijdstip der productieve handeling als basis-element der calculatie voor alle huishoudingen naar voren gebracht, terwijl wordt aangetoond, welke fouten gemaakt worden door de verwarring van uitgaven en waarden (m.a.w. door de vermenging van de functies van financieren en exploiteren). Verder worden de kostprijs en haar samenstellende delen in normatieve betekenis gesteld voor verkoopprijsbepaling, tariefstelling, efficientiebewaking en resultatenbepaling en wordt de organische verbondenheid van de duurzame productiemiddelen en de daarmede voort te brengen producten op de technische en economische karakteristiek dier productiemiddelen gebaseerd (n.l. in dat deel der theorie, waarin die productiemiddelen gesteld worden als voorraad van ter beschikking der productie verworven werkeenheden). Die bouw der theorie beantwoordt ten volle aan de eisen van modern bestuur der moderne productie-organisatie, ongeacht of zij goederen of diensten produceert dan wel beschikbaarheidsnuttigheden voortbrengt en ongeacht de juridische structuur der huishouding. Uiteraard echter zijn niet in alle gevallen alle problemen aan de orde, tot welker oplossing de theorie de sleutel geeft.

Deze theorie verbindt bovendien de verschillende technieken, welke in monografieën als kunstleren worden beschreven, standaardkostenbepaling, bedrijfsbudgettering, winstbepaling op korte termijn, analyse naar potentiële behoeften en hun waarschijnlijke ontwikkeling, enz. Juist daardoor is zij bijzonder geschikt voor de opbouw van het openbaar bestuursapparaat, wijl daar het gebonden zijn aan openbare critiek een grotere noodzaak schept aan eenheid van conceptie en logica van structuur dan in de onderneming.

c. de gecompliceerde structuur der te besturen organisatie.

$\mathrm{B}_{\mathrm{ij}}$ beide categorieën van huishouding (enerzijds die welke voor dim a b blz, 320 
recte bevrediging van behoeften verkoopbare diensten of beschikbaarheidsnuttigheden produceren en anderzijds die welke in ondernemend produceren goederen of diensten ter markt aanbieden) is nodig, dat het verantwoordelijk bestuur initiatieven en verantwoordelijkheden delegeert aan leiders van de onderdelen der organisatie. Deze functionele decentralisatie vereist de normatieve kostprijs in haar organische verbijzondering. Die verbijzondering gaf er in de twintiger jaren aanleiding toe, dat de kostprijs, zoals Limperg die formuleerde, in kringen der gemeente-administratie als organische kostprijs werd aangeduid bij het streven om die kostenbepaling als grondslag der efficientiebepaling te benutten. Bij de reorganisatie der rijksadministratie stond mij hetzelfde doel voor ogen.

De parallelisatie van producties - evenzeer als de phasenindeling naar organisch gescheiden productie-handelingen, hulp-afdelingen en nevenbedrijven - kent het particuliere bedijrfsleven evenzeer als de gemeenschapshuishouding. De grondslag van de parallelisatie in de ondernemende concerns moge een heel andere zijn dan de politieke beginselen, welke in de gemeenschapshuishouding de collectiviteit van producties van diensten en beschikbaarheidsnuttigheden bepalen, de administratie heeft alleen te maken met het feit, dat een combinatie van onderscheiden processen onder een centrale verantwoordelijkheid geplaatst is. Bovendien geldt het feit, dat in elk dier processen weer een hoofdleiding is, die bevoegdheden moet delegeren, wil zij haar verantwoordelijkheid kunnen dragen. Daarbij komt dan nog, dat de combinatie van verantwoordelijkheden in het openbaar bestuursapparaat een collectieve verantwoordelijkheid schept, waaraan de eenheid van conceptie niet mag ontbreken en de economische verdeling der te verwerven geldmiddelen over de verschillende vereiste producties van beschikbaarheidsnuttigheden een probleem van de eerste orde is. Ik geef dit coördinatie-vraagstuk een even centrale plaats als de politieke coördinatie, welke grondslag van het regeringsprogramma is.

Deze probleemstelling, welke $\operatorname{Dr}$ Ridder en mij bij de voorbereiding van de reorganisatie van het rijksbestuursapparaat (tijdens de bezetting) voor ogen stond, vond ik terug in de typering van het vraagstuk op het Congres international des experts-comptables, Parijs 1948, in de woorden van de directeur van het Institut de droit comparé der Université de Paris - de Controleur-Genéral R. Jacomet - :L'avènement et le développement de la fonction économique de l'Etat bouleversent les données traditionelles de la comptabilité publique. A la notion de regularité des opérations comptables se superpose en effet la notion de rendement". „L'administration d'un Etat aux activités ainsi étendues et dispersées et qui prélève sur la collectivité un tribut de plus en plus lourd faut témoigner - par le souci constant d'une organisation rationelle de ses services de son aptitude à fournir au public le maximum de satifaction au moindre prix de revient. Il est donc indispensable, qu'elle se préoccupe désormais de déterminer le coût réel de chacune de ses activités ainsi que les changements de valeurs des richesses de tout nature dont elle fait usage pour remplir ses missions".

„L'Etat moderne est conduit non seulement à assumer la direction ou l'animotion de la production, mais aussi à produire lui-même et à transformer des richesses. Il devient ainsi une grande entreprise dont le sort se trouve étroitement lié à celui de la communauté nationale. C'est un problème commun de production que l'Etat et l'industrie ont ensembli à résoudre". 
Een gemeenschappelijk probleem van productie; inderdaad is dit zo! Immers de traditionele onderscheiding verbruikshuishouding (voortbrengende naar de vereisten der betrekkelijke techniek de beschikbaarheids nuttigheden van openbare orde, etc.) en productiehuishouding (ter markt beschikbaarstellende voortbrengselen harer verbijzonderde techniek) is volkomen zinloos geworden. Naar mijn oordeel is zij steeds zinloos geweest, maar daaraan kan ik voorbijgaan, omdat ik hier geen historische analyse bedoel. Productie is verbruik van waarden, welke men bezit om andere waarden voort te brengen. Reproductief verbruik is een term. waarmede Arthur Spiethoff dit verband typeert. In Limperg's theorieën wordt het verbruik van de mens, als finaal consument, terecht gezien als de reproductie van het menselijk productie-vermogen. Er is een steeds gesloten kringloop van verbruik en productie; alleen is van belang om naar gelang van het vraagstuk, dat men bestudeert, de productieve en de consumptieve functie te scheiden. Wie dit eenmaal ingezien heeft, kan niet meer spreken over een ",principieel onderscheid" tussen verbruiksen productiehuishouding, teneinde de tegenstelling tussen „commerciële boekhouding" en "kameraalstijl" vast te houden.

\section{d. instemming en bestrijding der vernieuwingsgedachte.}

De huidige Nederlandse staatsadministratie is een vermogensrechtelijke boekhouding; althans dicht bij het doel om dit te worden. Verschillende der millioenennota's van de periode 1945/1952 spreken over die verandering; over haar voortschrijding en hare doeleinden. In verschillende publicaties heb ik de denkbeelden, waarop zij berust de toepassing der bedrijfshuishoudkundige theorieën — buiten de landsgrenzen moeten verdedigen en in mijn oratie deze in kort bestek aangegeven. Buitenlandse autoriteiten - onder meer de vroegere directeur van de federale begroting der U.S.A. de Heer Donald C. Stone, de Heer Jacomet, de Belgische Inspecteur-général des Finances Dr Gaston Dermouchamps, de Israelische State-comptroller Dr Moses en verschillende van zijn hoofdambtenaren, hebben de juistheid van de door de Nederlandse staatsadministratie ingeslagen weg exkend. Nog zeer onlangs heeft de Heer W. Rosenberg in een artikel in ,"The Accountants journal of New-Zealand" (November 1951) de juistheid der Nederlandse methode erkend en van daar uit een scherpe aanval gedaan op de handhaving van de kameraalstijl in het Engelse rapport van ..the Committee on the reform of government accounts" (H.M.S.O. Em) 7969 London); Dalton-committee.

Daartegenover zijn in binnen- en buitenland autoriteiten, welke deze "doorbraak" der traditionele onderscheidingen verwerpen en de kameraalstijl blijven aanhangen op formele gronden (zoals de Engelse Dalton-commissie bovenbedoeld) of op principiële gronden de d.z.z. voorgestane hervorming geheel of gedeeltelijk verwerpen. Hieronder valt ten onzent op de Tilburgse lector Dr D. B. J. Schouten in zijn (door mij overigens zeer gewaardeerde) dissertatie .Overheidsfinanciën". Behandeling dezer controverse in de kolommen van deze periodiek kan n.m.m. derhalve niet achterwege blijven. Ik zal daarbij ingaan op enkele punten van het Dalton-rapport, op uitingen vernomen in de Franse commissie voor herziening van budget en comptabiliteit, zowel als op die vernomen van het conservatieve deel der Israelische hoofdambtenaren en vooral op de bezwaren van Dr Schouten. Dat daarbij mijn in- 
zicht in de staatsrechtelijke betekenis van de machtsdelegatie in het openbaar bestuur aan de orde zal komen, is noodzakelijk. Dat ik daarbij een enkele maal in onze lezerskring bekende delen van Limperg's theorieënsysteem moet releveren om ze onder de bijzondere belichting van dit probleem te stellen, acht $i k$ niet te vermijden.

\section{Enige grondslagen van de inrichting van de administratie van het publieke bestuursorgaan.}

\section{a. het onderscheid tussen Staats- en bedrijfshuishouding.}

Begrippen en inzichten worden niet gevormd door gedachtenloos overnemen. Ter zake van het onderscheid in kwestie meen ik dat veelvuldig - zonder onderzoek naar hun juistheid — traditionele oordelen worden overgenomen.

Het wezenlijk onderscheid ligt in het verschil tussen voortbrenging met direct doel der behoeftebevrediging (de gemeenschap produceert voor de gemeenschap) en de voortbrenging met het doel een inkomen voor ondernemenden te verwerven, afhankelijk van de uitkomst en van het bedrijfsresultaat; een zo groot mogelijk inkomen. Voortbrenging is dan middel tot het inkomen, niet tot het doel van behoeftebevrediging; althans niet direct.

De vermeende oordelen moge ik nu onderzoeken om tot bevestiging van het wezenlijke onderscheid te komen.

Een onderscheiding tussen gemeenschapshuishouding en ondernemingshuishouding, waarbij de een gezegd wordt verbruikshuishouding te zijn, de andere productiehuishouding, moge in oppervlakkige beschouwing aangetroffen worden, enig nadenken zal leren, dat aldus het onderscheid in kwestie niet angegeven kan worden. Elke fabriek is eensdeels verbruiks- anderdeels voortbrengingshuishouding, voortbrengen toch is verbruik van waarden om andere te produceren. En daarin is alleen het rationeel verbruik productief. Men denke aan Spiethoff's uitdrukking ",reproductief verbruik". De consumptie van de mens ter bevrediging van zijn behoeften is niet anders dan het middel om zijn werkkracht te reproduceren; zelfs zijn verbruik voor ontspanning en genot valt daar onder. voor zoveel althans dat verbruik rationeel is. Oud-liberale traditie beperkte het product-begrip tot materiële goederen; een latere visie rekende de diensten mede, voor zover in ruilverkeer ter beschikking gesteld. Dat is echter alles een bekrompen begripsbepaling. Een gegronde reden is er niet voor. De gemeenschapsvoortbrenging direct voor de behoeften der gemeenschap zou dan productie zijn voor zover voor die diensten per eenheid kon worden betaald en voor zover voor die diensten als collectiviteit in de belastingen betaling wordt geëist, zou er van consumptie sprake zijn, die niet gelijk productie is. Dat ware een absurditeit; de beschikbaarstelling der autostrada in Italië (waar men voor het gebruik naar afstand betaalt) zou dan productie zijn. Hier te lande en in België en Frankrijk, waar de snelverkeersweg onder de beschikbaarheidsnuttigheden valt, zou er sprake zijn van uitsluitende consumptie! Evenzeer acht ik onjuist ter benadering van dit vraagstuk om tussen nieuwe of moderne en oude of klassieke taken te onderscheiden. De nieuwe taken liggen daarbij meer uitgesproken op economisch terrein. Men wil dan wel die als productief hebben, naast de klassieke, die consumptief zouden 
heten. Men vergeet dan echter, dat de klassieke taken evenzeer tot het economisch leven behoren. Openbare orde, rechtshandhaving, voorkomen van beschadiging der nationale integriteit hebben evenveel betekenis als factoren van economisch bestaan, als factoren van andere facetten van het sociale leven. De klassieke overheidstaak van verzorging van verkeerswegen (Rome) heeft wel zeer sterk een economische inhoud.

Alle overheidstaken behoren dus tot het gebied der productie. Consumptie, welke niet de productie dient, is verspilling. In Limperg's theorie zijn productie en consumptie dan ook terecht steeds beschouwd als verschillende aspecten van dezelfde technische activiteit. Overigens, het gaat bij het kostprijs-vraagstuk mede om de doelmatigheid van het verbruik te beoordelen. Elke beschouwing over overheidsfinanciën zal moeten toegeven, dat de contrōle op de doelmatigheid van het verbruik hier minstens even grote betekenis heeft als in de onderneming. Zelfs zou men kunnen zeggen, dat die contrôle in de Overheidshuishouding een meer dringende noodzakelijkheid is, omdat hier niet als in de onderneming een te grote ondoelmatigheid in het verbruik van voor de productie vereiste waarden wordt gekeerd door een optredend negatief resultaat. Evenzo keert - overal waar ter markt verkoopbare goederen of diensten worden geproduceerd - de bereikbare prijs een producentenbeleid, dat aan het product een grotere perfectiegraad zou geven dan door de verbruiker begeerd is of door hem betaald kan worden. De wal keert het schip! Het feit, dat winst beoogd wordt, impliceert maar in zeer beperkte mate het streven naar doelmatigheid in de productie. Het efficiëntiestreven is niet tot op winst-gerichte bedrijven beperkt. Integendeel, juist het feit, dat offers der voortbrenging uit de middelen der gemeenschap door dwang gedekt worden, moet - in de democratische rechtsstaat - ertoe leiden, dat geen groter offers gebracht worden dan onder gegeven omstandigheden vereist zijn voor de productieve doeleinden, welke de gemeenschap stelt. Waar dat toch geschiedt, is de Overheid niet voldoende bekwaam tot haar economische taak of vervult die op onjuiste wijze.

Wanneer de Overheid diensten of goederen laat voortbrengen, welke in marktverkeer worden beschikbaar gesteld, is het verschil met de ondernemende productie principiëel gelegen in het ontbreken van het winstmotief. De productie geschiedt in die gevallen in beginsel met het oogmerk om een zo groot mogelijk aantal personen in de gelegenheid te stellen om de diensten in kwestie te gebruiken; dus tot de kostprijs als som van tot die productie vereiste of onvermijdbare offers. Efficiëntie contrôle is in deze doelstelling eerste eis, de tariefstelling komt m.i. op de tweede plaats. Een gunstig bedrijfsresultaat is gevolg van samenloop van omstandigheden, t.w.: dat in het kader der gegeven doelstelling verlies vermeden moet worden (anders betalen belastingplichtigen voor het genot der dienstverbruikers); dat zekere voorzichtigheid moet worden betracht in de tariefstelling om verlies te voorkomen en dus voortschrijding van rationalisatie of efficiëntie in de productie niet tot tariefsverlaging kan leiden dan nadat zij in haar effect volkomen doorgewerkt is. Het feit, dat gemeenschapsbedrijven een monopolie hebben, blijkt uit deze beschouwing voor ons probleem zonder betekenis te zijn. Dat gemeenschapsbedrijven soms gericht kunnen worden op winst, waaruit andere uitgaven der gemeenschap bestreden zullen worden, acht ik een bijzonderheid, welke de principiële stelling niet stoort. Evenmin is dat het geval, wanneer om bepaalde redenen een productie door een gemeenschapsbedrijf met verlies geschiedt.

$\mathrm{m}$ a b blz. 324 
Ondanks het winstverschijnsel in de resultatenrekening dezer bedrijven, zijn deze bedrijven in economische karakteristiek nauw verbonden met productie van beschikbaarheidsnuttigheden. Beide behoren tot de directe voortbrenging dóór de gemeenschap vóór de gemeenschap. Slechts oppervlakkige waarneming zou ertoe kunnen leiden om deze bedrijven - op grond van mogelijke gunstige overschotten - enige analogie met ondernemingen toe te schrijven. Ondernemingen hebben als doel het verwerven van zo groot mogelijke winst, bij gemeenschapsbedrijven is het resultaat het bijproduct van doelmatig en voorzichtig (dus rationeel) beleid.

Karakteristiek voor de voortbrenging door de gemeenschap voor de gemeenschap van beschikbaarheidsnuttigheden is, dat de kosten door de bevoordeelden als collectiviteit worden betaald in de belastingen; andere doeleinden der belastingen daargelaten. In het huidig democratisch bestel zal de gemeenschap, welke de collectiviteit doet voortbrengen, door hare productieorganen de samenstelling der collectiviteit en de graden der perfectie in de voortbrenging der individuele nuttigheden moeten bepalen. Deze taak is geëndosseerd aan de volksvertegenwoordigende organen. Daarmede komen we op het budgetrecht, waarbij de wetgevende macht, die het publieke productieplan vaststelt. De begroting is machtiging en taakoverdracht.

b. de "publieke administratie" - evenals de particuliere bedrijfshuishouding - beheerst door waardeverbruik.

$\mathrm{Bij}$ beschikbaarheidsnuttigheden is geen band te construeren tussen de kosten der beschikbaarstelling en het nut, dat degene verkrijgt, die van de beschikbaarheid gebruik moet maken. De politieagent, die de inbreker grijpt in de misdaad, heeft voor de benadeelde huisbewoner zelf een geringer nut dan degenen hebben, die van zulke bezoeken verschoond blijven door de beschikbaarheid van een actief politiecorps.

$\mathrm{Er}$ is dus ter zake van geproduceerde beschikbaarheidsnuttigheden geen opbrengstwaarde bepaalbaar. Het gaat dus niet op, dat er voor elke beschikbaarheidsnuttigheid twee gecoördineerde waardebegrippen $z i j n$. De opbrengstwaarde is alleen bepaald in de collectiviteit der beschikbaarheidsnuttigheden, welke de gemeenschap wenst te zien voortgebracht. Er is echter wel een vervangingswaarde voor elke beschikbaarheidsnuttigheid op zichzelf; n.l. de kosten van hare voortbrenging in de vereiste perfectiegraad. Die kosten kan men omschrijven als de offers aan welvaart der volksgemeenschap, welke de voortbrenging der beschikbaarheidsnuttigheden vereist. Het probleem der doelmatigheid in dat productieplan houdt - binnen het kader van de aangenomen collectiviteit en van de perfectiegraden der afzonderlijke voortbrenging - de vraag in of deze diensten worden geproduceerd tot het vereiste minimum aan kosten en of de druk op het inkomen, welke de betaling voor de aldus geproduceerde collectiviteit van nuttigheden veroorzaakt, in verantwoorde relatie staat tot de bestaande volkswelvaart op het moment in kwestie. Die laatste vraag vereist kwantitatieve voorstelling van die volkswelvaart: nationaal vermogen, nationaal inkomen. Dit brengt ons op de in ons land bekende methode de staatsbegroting te presenteren tegen de achtergrond van de desbetreffende cijfers van het z.g. ,nationaal budget" van het Centraal Planbureau. Ik laat de vraag naar de theoretische juistheid der namen buiten bespreking. Ik kan echter niet nalaten

m a b blz. 325 
erop te wijzen, dat de vergelijkbaarheid (of beter het vereiste in elkander passen) van staatsbegroting en nationaal budget impliceren moet, dat bij beide naar de waarde der betrokken grootheden gerekend is. Men moet zelfs rekenen met de waarde, welke die grootheden waarschijnlijk zullen hebben in de periode, waarvoor de budgetten gemaakt zijn. Indien men op basis van historische waarden (uitgaven) calculeert in plaats van waarde, dan telt men in beide becijferingen bedragen op, welke niet de huidige kosten, maar verwervingsuitgaven van verschillende voorbijgegane momenten voorstellen. De ontoelaatbaarheid dezer opstelling is al elders aangetoond; de onjuistheid der onderlinge vergelijking van de sommen dier optellingen vloeit daaruit voort. Er is echter meer. Vertering van bestaande volkswelvaart of van het vermogen van Staat of gemeente mag niet anders geschieden dan openbaar en met machtiging door de volksvertegenwoordiging. Elke calculatiemethode in de openbare dienst, welke - als de traditionele — zulk een vertering op gecamoufleerde wijze kan impliceren, mag niet worden getolereerd in een democratisch bestel. Uit een en ander volgt, dat zowel bij de benadering van het volks inkomen en van de belastingontvangst, als bij die van de kosten der voortbrenging door de gemeenschap van vervangingswaarde moet worden uitgegaan. De belastingen dienen dus met vervangingswaarde te rekenen, zowel bij de inkomens uit bedrijven als bij lonen en salarissen. $\mathrm{B}_{\mathrm{ij}}$ wijzigingen in de kosten van levensonderhoud moet dus gerekend worden met het effect van de waardewijzigingen der vereiste goederen op de draagkracht van de bevolking en van hare inkomensgroepen. ${ }^{1)}$

Hier blijkt, dat - nadien, sedert de technische tevolutie, - voor de productie der beschikbaarheidsnuttigheden duurzame (ook zeer langdurig bruikbare) productiemiddelen vereist zijn en massale voorraadverwerving doelmatig is - de gelijkstelling van uitgaven aan waardeverbruik tot een funeste verwarring in de inzichten moet leiden en een - over twee heupen - hinkende politiek moet creeren.

Van de zijde van degenen, te wier nutte de beschikbaarheidsnuttigheden geproduceerd worden, geldt nog de vraag of niet de voortbrenging dier nuttigheden in hun collectiviteit een groter offer uit hun individuele welvaart vraagt; een offer, dat - naar hun oordeel - groter is dan het nut, dat zij voortgebracht achten. Dit is een typisch vraagstuk, dat meerdere problemen inhoudt: n.l.: is de algemene belastingdruk niet te hoog; is die druk wel juist verdeeld over inkomensklassen (mede gezien de betekenis voor de klasse van het totaal resp. van de afzonderlijke beschik baarheidsnuttigheden); belast de druk het heden niet te veel ten faveure van de toekomst of wentelt zij niet de huidige lasten op de toekomst af?

Hier neemt het probleem een vorm aan, waarin scheiding van kapitaal-

1) De draagkracht-theorie der belastingwetenschap moet er naar mijn mening van uitgaan, dat boven de reproductiekosten van de arbeidscategorie, waartoe men behoort (later in dit artikel te bespreken) een consumersurplus genoten wordt, waaruit het verbruik aan misbare welvaartsvoorzieningen wordt gefinancierd. Binnen de reproductie valt het proportionele deel, waarin ieder relatief profijt heeft van de geproduceerde beschikbaarheidsnuttigheden. Een hogere inkomen geeft wel kans, dat de genieter een groter profijt van die diensten heeft, maar de daaruit volgende progressie kan alleen zuiver gesteld worden, indien daarbij niet naar het nominale, maar naar het reële inkomen gerekend wordt. Bij deze argumentatie kan aangepast worden wat Prof. de Langen eens schreef, dat het draagkracht-probleem anders ligt, wanneer het hogere inkomen uit extra-arbeid vloeit dan wanneer het gevolg is van arbeidsloos inkomen of van de combinatie daarvan met inkomen uit abreid. 
verwerving en exploitatie niet afhankelijk kan zijn van mogelijkheden van het plaatsen van leningen, noch van monetaire positie, maar van de technische en economische vereisten met de voortbrenging - de exploitatie verbonden. Het probleem van scheiding van kapitaal- en exploitatierekening krijgt hier uit de aard van de rechtsverhouding tussen bestuur en bestuurders in de democratische staat principieel dezelfde gedaante, welke het in de bedrijfshuishouding heeft. De eis van exactheid is bij de Staat - om reeds genoemde redenen - gradueel zwaarder. De eis om de verbruikte werkeenheden naar vervangingswaarde te calculeren, krijgt mede daardoor een meer dwingend karakter.

Herinneren wij ons hierbij, dat de graad van perfectie, waarin de beschikbaarheidsnuttigheden geproduceerd worden - juist door de aard dier productie - bij de gemeenschapshuishouding een groter probleem schept dan bij de ondernemingsgewijze productie. Het ontbreken van de overdrijving kerende werking van de opbrengstwaarde werd reeds genoend. Het probleem ligt echter dieper.

Doelmatige verhoging der perfectie bij de voorbrenging van beschikbaarheidsnuttigheden verhoogt het nuttig effect. Groter aantal politiesquadrons - d.i. verhoging der perfectie (om een voorbeeld te noemen) - verhoogt de veiligheid; zo ook betere materiële uitrusting. Een hogere perfectiegraad vereist echter een groter waardeverbruik. De directeurgeneraal van een dienst heeft zuiver gesteld de taak om de hoogstbereikbare graad van perfectie na te streven, die met handhaving der uiterst bereikbare efficiëntie, te combineren is. Evenwel boven zeker punt zal de kostencurve bij verhoogde perfectiegraad asymptotisch aan de y-as gaan stijgen, terwijl, ware het beschikbaarheidsnut te meten, een parabolisch verloop asymptotisch aan de $\mathrm{x}$-as zou zijn waar te nemen. Het snijpunt dezer lijnen zou de grens aangeven boven welke de productie niet voortgezet mag worden. De opbrengstlijn is echter voor de enkele dienst niet op te stellen, zoals reeds betoogd is. De bepaling van het punt is dus alleen bij intuitie mogelijk, derhalve steeds van persoonlijk inzicht afhankelijk. Er treden echter voor het geheel der collectiviteit enige waarneembare punten naar voren, n.l.: is de druk voor de collectiviteit niet te hoog. lopen de perfectiegraden der verschillende diensten niet meer uiteen dan met hun belangrijkheid in de collectiviteit te rijmen valt (toepassing Gossense wet). Anders gezegd luidt dit: is er wel voldoende coördinatie in de besteding der te heffen middelen. Dit is de vraag, welke een bepaalde functie in het hoogste bestuursbeleid doet ontstaan, n.l. de coördinatie in de budget-voorstellen welke het Kabinet aan het Parlement doet. In onze wetgeving is die functie aan de Minister van Financiën opgedragen. $Z_{\mathrm{ij}}$ is ondergebracht in de dienst der rijksbegroting. De combinatie ervan onder een ministriëel beleid met de zorg voor geldwezen en belastingheffing past in het kader onzer beschouwing. Daarnaast is er in de samenstelling der collectiviteit en in de beoordeling der perfectiegraden het politiek element, dat het Kabinet te beoordelen heeft en in hoogste ressort het Parlement regardeert. Dat gezagsorgaan kan het politiek plan naar mijn mening alleen goedkeuren onder voorwaarde dat niet slechts een repressieve contrỏle een overmatig waardeverbruik (dat niet bij authorisatie is uit te sluiten) zou signaleren maar ook een voorkomen ervan verzekerd is. Hierbij is het om het even of dit zaken zou betreffen, welker aanschaffing of voorziening dit jaar gefinancierd moet worden, dan wel verbruik van waarden, welke de organen van het bestuursapparaat reeds bezitten en die, voor de continuiteit hunner productie onmisbaar zijnde, 
onder de klem van vervangingsnoodzaak liggen. Daarnaast heeft het Parlement uiteraard goed te keuren de aanschaffingen, welke dit jaar voor latere productie vereist zijn. Goedkeuring der exploitatie- of productiekosten sluit voor de lopende dienst in goedkeuring van de financiering der vereiste uitgaven (gewone dienst). Het geheel der financiering van verwerving van duurzame productiemiddelen en van voorraden van vlottende valt onder kapitaaldienst, mits men die volledig houdt naar wat een economisch bestel vereist. Invoering van dubbele boekhouding (met balans en exploitatierekening naar vervangingswaarde) maakt mogelijk om in begroting en rekening de functies van financieren en exploiteren op de juiste wijze tot uitdrukking te brengen. Het huidige Nederlandse systeem gaat in deze richting. Het plan der beleidsvoering geeft daarbij de kosten van de uit te voeren diensten overeenkomstig hun organische plaats in het bestuursapparaat. In de kosten voor elke dienst - in organisch verband en categorische orde - blijken dan zowel de kosten, welke aan uitgaven identiek zijn als die, welke een verbruik van door vroegere uitgaven verworven waarden inhouden.

Het budget als huishoudplan moet dus in de vermoedelijke waarde van het budgetjaar zijn opgesteld; de vervangingswaarde benadert die het beste. Dit probleem kent ook de ondernemende bedrijfshuishouding. Mijn boek "Bedrijfsbegroting en Bedrijfsbeleid" sla men er op na.

Men verantwoorde in de boekhouding - evenals in het particulier bedrijf vereist is - het verbruik naar de vervangingswaarde (wijl er geen andere waarde is). Men legge de belasting op ter dekking van de naar vervangingswaarde berekende kosten en kan aldus - over het gehele staatsapparaat gerekend - de dit jaar te vervangen duurzame productiemiddelen financieren uit het totaal der afschrijvingen op alle productiemiddelen (op vervangingswaarde berekend).

Aldus hebben ook het Parlement en de Regering het juiste beeld der waardeverhouding in de verschillende diensten en komt men ook tot een juiste coördinatie in de zin der Gossense wet. $\mathrm{B}_{\mathrm{ij}}$ de uitgaven-begroting kan die coördinatie nooit juist zijn, omdat er slechts een deel der kosten met uitgaven identiek is en voor het overige de verwarring van uitgaven en kosten een scheef beeld van het waardeverbruik van een bepaald jaar geeft; slechts in die zeldzame gevallen, waarin bij elke dienst de jaarlijkse aanschaffingen aan de afschrijvingen gelijk zijn zou in perioden zonder waardeverandering van noemenswaardige betekenis uitgaven en kosten voor de kapitaaldienst gelijk zijn. Dit toont voldoende het onjuiste aan van het argument, dat deze gelijkstelling op grond van jaarlijks regelmatig wederkerende vervangende aanschaffingen wil verdedigen.

\section{c. Weerlegging van Schouten's vasthouden aan "historische kosten".}

Het is mij volkomen onbegrijpelijk, dat een voortreffelijk analyst en ervaren theoreticus als Dr. D. B. J. Schouten in zijn - overigens door mij buitengewoon gewaardeerde - dissertatie (Overheidsfinanciën in de volkshuishouding) tot de opvatting komt, dat calculatie naar waarde der verbruikte ,zaken", geen grondslag mag zijn voor het beleid in de staats en gemeente-huishouding. Schouten meent, dat de calculatie naar uitgaven gehandhaafd moet blijven. Hij zegt, dat voor de Overheids-administratie "historische kosten" maatgevend zijn. Ik moge hier nog even bij stilstaan.

Schouten beschouwt blijkbaar het gebruik der vervangingswaarde als een bepaalde techniek van waardebepaling en winstberekening, staande 
naast technieken, welke met andere waardebegrippen werken, zodat dus soms de ene techniek, soms de andere de beste aanpassing aan het doel geeft. Zo echter hebben de verdedigers der vervangingswaarde die nooit gesteld. Men leze er mijn laatst verschenen boek en mijn jongste opstel in dit maandblad op na. De vervangingswaarde is onder alle omstandigheden en voor ieder de kwantitatieve voorstelling van de betekenis, welke goederen en diensten hebben voor de bezitters, zo lang zij in de samenleving in regelmatige en continuele stroom worden voortgebracht. Slechts in bepaalde gevallen - n.l. wanneer de continuïteit verbroken is en de voorraad niet vervangbaar is - treedt het alternatief der opbrengstwaarde in de plaats der vervangingswaarde. Dit is het kort begrip der waardeleer.

De indicatie ,vervanging" bij de benoeming van het waardebegrip dient alleen maar om de tegrenstelling tot de opbrengstwaarde aan te geven; dus om het alternatief uit te drukken. Zij, die deze theorie als kunstleer hanteren $\sim$ d.i. met de doelstelling van een bepaald effect motiveren - kunnen anderen in de waan brengen, dat vervangingswaarde een calculatie-grondslag is, welke naast andere calculatie-grondslagen gebruikt kan worden. Blijkbaar is ook de Heer Schouten onder de invloed van die misvatting gekomen.

In het verleden betaalde prijzen, het zij ten overvloede herhaald, bepalen - n'en déplaise de traditionele thesen der boekhoudtechniek de waarde niet meer op latere momenten. De aanschaffingsprijs betaald bij verwerving, is voor het waardevraagstuk zonder betekenis. Historische kosten is dus al evenzeer een onjuist begrip; historische kosten bestaan niet. Het woord is misleidend.

De samentelling van waarden van verschillende momenten( werkeenheden van gebouwen uit vorige eeuwen en decennia, van schepen, machines en andere productiemiddelen) met verschillende tijdstippen van aanschaffing, verbruik van vroeger verworven voorraden bijeentellen is even fout als het bijeentellen van tellers van niet op eenzelfde noemer gebrachte breuken.

De uitgaven kwamen eens - op het moment, dat zij een verwerving financierden - met waarde overeen. Het verbruik van het verworven bezit moet echter naar waarde op het moment van verbruik gecalculeerd worden en niet naar een veelheid van waarden betrekking hebbende op verschillende momenten uit het verleden. Het totaal van waarden uit het verleden van verschillende werkeenheden van allerlei productiemiddelen - op verschillende momenten verworven - kan niet aangeven het offer aan verbruik van nationale welvaart van het huidig moment. De kapitaalgoederen van de verschillende secties van het openbaar bestuur staan evenzeer onder de klem van de vervanging, indien men de volkswelvaart en het staatsbezit wil handhaven, als de kapitaalgoederen van de onderneming. Het gehele voorafgaande betoog acht ik een bewijs van Schouten's onjuiste stelling - ten deze — in zijn uitstekende boek.

Schouten's verkeerde uitgangspunt, nl. dat hij onderscheidt bedrijven, welke voor een markt werken en de Overheid, die collectieve goederen en diensten doet verzorgen (in onze termen: beschikbaarheidsnuttigheden voortbrengen). Hij zegt, dat bij laatstgenoemde categorie geen sprake kan zijn van een ,relatieve ruilwaarde" en dat bij gebrek aan „marktprijs" de waardesom van de collectieve goederenvoorziening gelijk zou zijn aan de historische kosten. Uit het gegeven betoog volgt reeds, dat dit nooit waar kan zijn. Historische kosten is een verwarrend begrip, om- 
dat het een ontoelaatbare optelling impliceert. Het onjuiste in de traditionele uitgaven-calculatie heb ik voldoende bestreden. Ook blijkt, dat Schouten het argument om de vervangingswaarde niet te gebruiken, ontleent aan de ontstentenis van de opbrengstwaarde en tenslotte, dat hij niet rekent met de functie van een normatieve kostprijsbepaling ter bewaking van de efficientie. Hij schakelt dus juist uit, wat de betekenis van het kosten- en waardeprobleem in de Staats- en gemeentehuishouding is.

Het argument, dat de Overheid geen ondernemersfunctie, maar een productiefunctie heeft, zou alleen dan betekenis hebben, indien het gebruik van de juiste waarde de betekenis zou hebben om de regelmaat van het ondernemersinkomen te verzekeren. Daarin kan echter nooit een bewijs voor zijn stelling liggen, omdat het postulaat een aprioristische uitschakeling van toepasbaarheid der Limpergiaanse waardeleer op de Staatshuishouding (èn op de Staatsbedrijven) inhoudt. De waardeleer is echter niet door Limperg geformuleerd als recept of voorschrift (kunstleer) ter instandhouding van ondernemersinkomen, bedrijfssubstantie of goederenstroom, maar als consequentie van het feit, dat de maatschappelijke productie in regelmatige stroom geschiedt en derhalve de waarde alleen van de vervangingswaarde kan afwijken, indien de continuiteit van de goederenstroom verbroken wordt. Dit is bekend genoeg.

Ik acht hiermede - gezien het voorafgaande betoog - Schouten's verwerping mijner theorie weerlegd.

(Slot volgt). 